\title{
A Critical Discourse Analysis of Language in Ghanaian Newspaper Editorials
}

\author{
By Justine Bakuuro * \& Africanus L. Diedong ${ }^{*}$
}

\begin{abstract}
The study explores the linguistic devices, approaches and styles in media discourse that are used to stake claims to knowledge, to influence attitudes and to promote critical thinking, among other functional roles of language. The study was equally interested in knowing the outcomes of the choice of these linguistic devices as far as communication is concerned. Linguistic devices such as modality, evaluative adjectives, adverbs, generic phrases, rhetoric and idioms among others, are used to state opinions, make predictions and influence attitudes. The study hypothesises that the study of language can be used in particular ways, so intended by the user, to achieve specific purposes. Eight different newspapers: The Daily Graphic, The Ghanaian Times, The Mirror, The Crusading Guide, The Insight, The Independent, The Catholic Standard and The Daily Guide, editorial excerpts were culled and used for the study of language use in newspaper editorials. The styles used and the reasons behind the choice of those devices and styles are closely looked at in the analysis. With Systemic Functional Linguistics, complemented with Van-Dijk's theory of Media Discourse as models of analysis, the study is theoretically anchored. The study concludes that editorial writers use linguistic devices to express different shades of attitude and opinion, to influence, shape or re-shape their readers' attitudes and to promote critical thinking of readers.
\end{abstract}

Keywords: Linguistic Devices, Media Discourse, Communication, Language, Styles.

\section{Introduction}

Language is the vehicle a person uses to convey his/her ideas about the world. It fashions out or polishes our attitudes and general behaviour. Language is a network of communication that helps one to assess his/her thoughts. We use language to convince and impact others, create humour and to display our love for one another. Truly, language is key to man's life and general existence. According to Opara (2011:1) 'language is essentially a way of behaving and making others behave'. With the help of language, we are able to express many opinions, ideas, emotions and attitudes. Additionally, it elicits a variety of ideas and feelings from the people we interact with in communication.

In the words of Finegan (2012:5), 'language is a vehicle of thought, a system of expression that mediates the transfer of thoughts from one person to another'. That means language enacts very vital roles in life since it is a way of social practice. It performs many communicative functions. It entails evidential or propositional information. Brown and Yule (1983:6) refer to this as the 'primarily transactional' role of language. They argue that in primarily transactional language, what the sender has in mind is the efficient and effective transmission of

*PhD Student, University of Ghana, Ghana.

${ }^{*}$ Senior Lecturer, University for Development Studies, Ghana. 
information. Therefore, the use of language in such a manner is message inclined while the function that has to do with the expression of social relations and personal attitude is deemed interactional, according to Brown and Yule (1983).

Finegan (2012) also envisages the basic role of language as connecting meaning to expression or usage as she puts it, 'Language is a vehicle for verbal expression of thoughts and feelings' (Finegan, 2012:5). Thus, language brings about innovativeness in the enactment process of communication. It is a tool of togetherness that binds us in our daily lives.

Language is used to express cogent and explicit ideas and beliefs which have the ability to change, implicate, convince and redirect the thinking of people in media discourse, particularly the print media. Language is portrayed as a catalyst for persuading and empowering people, taking into consideration the patterns of discourse in the Ghanaian print media.

In this regard, Alder and Rodman (2000:79) opine that "there is an intrinsic power in language to shape opinions and attitudes". The language that is used in the media equally expresses concepts, ideologies or at least, mirror human attitudes (Malcom, 1997).

Language novices do not seem to notice the power in language use which affects ideologies, moulds or remoulds conduct, attitudes or ideas. Moreover, they do not observe that language can negatively or positively affect public opinion or enhance critical reasoning and influence actions on critical current issues of our society. Often, this intrinsic power of language is either not noticed or is ignored by many people. Discourse in the media therefore gives people convincing thoughts which shape their opinions about issues affecting them.

This paper takes a look at the linguistic choices employed in selected Ghanaian newspaper editorials to express diverse opinions and attitudes and to spark critical thinking. It also seeks to scrutinise the way editorial authors engage these devices to examine the potentiality of state of affairs, influence people's opinion or belief and ultimately shape their attitudes towards happenings around them.

\section{Discourse Analysis and Newspaper Editorials}

Discourse analysis is 'the study of the ways in which language is used in texts and contexts' Nordquist (2013:1). Hence, it is simply a way of looking at the nature of language and how it is linked to the integral issues of society. Abrams and Harpham (2005) also posit that discourse analysis involves the use of language in a running discourse which involves the interaction of a writer and a reader in a specific situational context and within a framework of social and cultural conventions.

In general terms, one may see discourse analysis as a general term for a number of approaches to analyzing written, vocal or sign language use or any significant semiotic event. "Discourse analysis focuses on the meaning we give to people's words so as to make ourselves better, more humane people and the world a better place" (Norquist, 2013). Therefore, the analysis of discourse entails a close 
examination of the use of language and the implicitness of meaning in texts.

Newspaper editorials express ideologies and comment vividly on contemporary social, political, and economic issues. A discourse analysis which is based on social, political or economic ideology is a critical study. To this end, this study is a critical discourse analysis of the print media.

Weintraut (2013:1) asserts that an editorial is 'an article that presents the newspaper's opinion on an issue. Editorials are meant to influence public opinion, promote critical thinking and cause people to take informed decisions on issues of political, economic and social concern to society. For Shepherd (2013:1), an editorial is 'a way a reporter weaves his own personal opinion into a story'.

Still on editorials, Bilal et al. (2012:746) posit that editorials 'shape and build the ideology of their readers'. They reflect the opinion of a periodical since they are pieces of opinion documented by the senior editorial staff for publication in a newspaper or magazine. Editorials come in various forms. Hence, some explain or interpret sensitive or controversial issues. Some constructively criticize actions, decisions or situations and provide solutions to the problems identified. Editorials of persuasion aim at seeing immediately the solution and not the problem. Furthermore, well written editorials influence public opinion on current issues in the society. Weintraut observes that few editorials commend people and organizations for something well done (Weintraut, 2013).

\section{Research Objective}

This study seeks to explore how language, as the vehicle for communication, can be used to convey specific ideas as intended by the speaker or author to his/her audience. In this light, we are studying language as a manipulative tool which one can use to send intended, specific information as the sender so desires.

\section{Assumption of the Study}

Principally, the study thrives on the assumption that language is organic in nature and can be manipulated by the user to achieve intended goals. This hypothesis finds expression in Systemic Functional Grammar theory. The study therefore attempted putting this theoretical hypothesis to test with its analysis of newspaper editorials.

\section{Theoretical Underpinning}

The newspaper editorials analyzed in this study contain linguistic devices used for evaluation of issues, expression of opinions and attitude, and promotion of critical thinking as earlier indicated. Therefore, the Systemic Functional Grammar and Van-Dijk's theory of Media Discourse are relevant and most suitable in this study. 


\section{Systemic Functional Linguistics}

The major proponent of Systemic Functional Linguistics (SFL) is M.A.K. Halliday. Language, according to SFL, is a symbolic instrument used for communicative purposes (Malmkjaer and Anderson, 1991). SFL explains language from the way it is actually used in discourse and not just on the formal relations between linguistic units. Thus, language is viewed as a system of meaning potentials. Opara (2009:7) notes that 'funtionalists focus on the possible connection between form and function'. Therefore, systemic functional linguistics focuses on what people do with language. This study adopts the systemic functional approach to linguistics by depicting how linguistic patterns unravel ideologies, express opinions and attitudes, show persuasion and evoke critical thinking among others. The study further shows how the devices equally reflect opinions, shape or reshape ideas.

Systemic functional linguistics recognizes three meta-functions which are ideational, interpersonal and textual. The ideational function refers to the way language is used in expressing the realities of human experience.

Ajayi (2009:587) stresses that 'the ideational meanings relate to what is going on in the world, that is, how people use language to articulate experiences. They relate to how words are used to express actions, objects, places, events, people, things and ideas'. The interpersonal function gives individuals the opportunity to express their attitudes and establish personal and social relationships. This angle of function of language equally deals with how people express their judgment of social issues and how they use language to influence others. The textual function expresses the structure of information or how language is organized to achieve goals and to produce a cohesive text (Opara, 2009).

The ideational and interpersonal meta-functions are relevant to this study because the study examines how language is used to express human experiences in the editorials (ideational meta-function). Furthermore, the study portrays how language conveys attitudes, judgments and opinions in our contemporary world (interpersonal meta-function).

\section{Van-Dijk's Theory of Media Discourse}

The main tenet of this theory is that discourse analysis is an ideological analysis and that language gives meaning and meaning can be analyzed through discourse analysis. Van-Dijk (1998) stresses that ideologies are typically expressed and reproduced in discourse and communication.

This theory is relevant to the study since the analyses of the newspaper editorials help to bring out the underlying meaning of the linguistic devices used in the discourse.

Furthermore, Boyd-Barret (1994) states that the Media Discourse theory calls for a thorough analysis not only of the textual and structural level of media discourse but also for the analysis at the production or comprehension level. It implies then that the theory will allow us to do the deeper analysis of how understanding is crafted by the writers for the consumption of readers of these editorials. 


\section{Methodology}

Using the purposive sampling technic, we selected a total of 25 editorials from the eight sampled newspapers. These editorials were published daily or weekly over a span of time - August 2017 to April 2018. The editorials are culled from The Daily Graphic, The Ghanaian Times, The Mirror, The Crusading Guide, The Insight, The Independent, The Catholic Standard and The Daily Guide. Therefore, the data analysed in this study are editorial excerpts from the eight selected newspapers. The editorials were selected randomly and the relevant excerpts were copied verbatim. These data were subjected to content analysis based on the linguistic devices found in the editorials. The study is therefore a typical and critical observation of how language operates functionally to influence human life.

\section{Data Analysis}

Different linguistic devices were found in the newspaper editorials. Some of them were geared towards expression of different attitudes, promotion of critical thinking and expression of opinions and ideas to reshape attitudes among other social variables. Also, some devices showed the assessment of the potentiality of a state of affairs in the society and the statement of different claims. In this study, the focal elements of language which we set out to investigate include: use of modality, use of evaluative adjectives and adverbs, expressing modality using reporting verbs, use of generic phrases of modality, use of rhetorics and the use of idioms.

\section{Modality}

Modality is concerned with the writer's assessment of an attitude towards the potentiality of a state of affairs. It is a resource which writers use when they are staking claims to knowledge. Modality allows them to state different kinds of claims like assertions, opinions, hypothesis speculations (Cameron, 2001).

In the editorials, modal auxiliary verbs such as 'must', 'may', 'can', 'will', 'should', 'would', 'could', 'ought to', 'might', were used to express modality. The modal auxiliary verbs used in the editorials under study allowed the writers to attach expressions of belief, attitude and obligation to the statements they made.

The following excerpts depict the use of modal verbs:

1. Nonetheless, government should do something about the proliferation of these so called vigilante groups since that could easily undermine the peace we are currently enjoying.

2. The youth will undergo technical training in Information Technology so as to make them employable.

3. In spite of these minor chieftaincy disputes arising from time to time in various parts of the country, Ghanaians should be thankful to God for the 
peace and tranquillity in the country.

4. Parliament may rise anytime soon.

5. It could be inferred from the Minister's speech that the programme needs more funding.

6. The local government should take proactive measures to ensure that this is checked.

7. Our leaders should be advised on the need for periodic medical check-ups to forestall such occurrences in future.

8. This is cruel, and the offenders must face the wrath of the law.

9. Empowering young women will definitely boost the economy beyond imagination.

10. Sentences must be deterrent enough.

11. This will at least assure the victims that their attackers are going to face punishment.

12. We can hardly understand this move taken by Civil Society.

13. They might just have returned from their first leg of the World Cup qualifiers.

14. Parents ought to put an eye on their wards during the holidays to know the sort of moral training they are picking up from school.

15. It would interest the average Ghanaian to know these heart-breaking revelations about salaries and wages of government appointees.

16. This innocent girl would drop out of school.

17. People can continue to call us names but we will continue the fight until victory is ours.

18. It might have been one of the unsuspecting prostitutes that was shot in the process.

19. Ghana must work again.

20. The accident may have occurred in the early hours of Wednesday.

21. The man proved to be a warrior of his time but many say he could do better.

In the excerpts above, the writers, while reporting the contemporary issues at stake, express their attitudes towards the issues by using modal auxiliaries. They provided the information and went on to show their attitudes towards the events using these modal verbs.

In the excerpts, numbers $1,3,6,7,14,8,10 \& 19$ showed that certain courses of action needed to be taken as a matter of necessity and a certain level of compulsion through the modal auxiliaries 'should', 'must' \& 'ought to'. The extent of benefit those actions or inactions could yield on society are adequately expressed through these modal auxiliaries, bringing out the writers' attitudes to the events described. They also portray the obligations that actors in the particular events were expected to carry out. By painting this picture of obligation on the part of powers that be, the readers are stimulated to think critically about issues affecting them and to demand what is legitimately theirs. The editorial writers could have made their points without employing these modals, but their choice of them is to enable them convey specific intended messages. This is very much in 
tune with Systemic Functional Linguistics which sees language use as a process of making choices for specific purposes.

In excerpts $2,9,11,15 \& 16$, the editorial writers expressed predictions of future events or happenings using the modal auxiliaries 'will' \& 'would'. They appear to be certain about the happenings or events in question, applying their own intuitive abilities to judge issues in life. It therefore remains their opinion, which could be disputed anyway, that those events were going to happen. This is yet another expression of their attitudes towards the state of affairs presented.

The excerpts in 4, 5, 12, 13, 17, 18, 20 \& 21 express different angles of possibility through the auxiliary modals 'may', 'can', 'could' \& 'might'. How actors could take relevant steps to curtail, solve, enhance, ameliorate or control situations and events have been expressed by the writers using these modal verbs once again. This provokes critical thinking among the masses and speaks of the writers' attitude towards the state of affairs in the specific statements made.

In the foregoing analysis, we see the choice-based approach to language as entailed in SFL. The view that language is based on individual choices to arrive at various meaning potentials is clearly demonstrated with the writers' choice of modal auxiliary verbs. The writers could have used different verb forms if they intended to mean differently.

\section{Evaluative Adjectives and Adverbs}

The editorial writers employed some highly evaluative adjectives and adverbs as linguistic devices, again, to express their attitudes towards the pathetic state of affairs in the Ghanaian society. Some examples studied include:

1. In his usual pensive mood, the former president sat with his arms folded across his chest.

2. In such an atmosphere of profound disillusionment, circumspection as well as a large dose of intellectual humility is required on the part of those in charge.

3. President Nana Addo, of course, did not create the sorry state of modern Ghana.

4. At almost mid-term in office, there is still no urgent sense of crises.

5. The President does not help matters by pretending that everything is normal. For it is demonstrably not so.

6. They know from watching television and reading the newspapers every day that the seemingly elusive dividends of democracy have been cornered exclusively by a self-serving elite.

7. This means absolutely nothing to those in the majority who subsist on this meagre minimum wage a day.

8. Frankly, the political establishment should try and live on the minimum wage and see how much they can cope with its brutal reality.

9. It is precisely this lack of empathy that is so glaring and profoundly incompatible with the ethos of a democracy.

10. Needless to say, the insatiable greed that engulf government 
functionaries whilst they are still in office accounts for the vehement protests we see from opposition parties who feel they no longer belong to this nation.

11. Unexpectedly, the president lashed out at his political opponents in a strong-worded statement read by him on Wednesday evening.

12. We simply cannot afford to lose this great sense of nationhood bequeathed to us by our forebears under such reckless conduct.

The editorial writers did not only present some factual information of events in Ghana but evaluated the events through the use of the adjectives and adverbs marked bold in each excerpt above. The statements are indeed a revelation of some facts about the current socio-political terrain in Ghana. The reporters, again, have shown their attitude towards this state of affairs by their use of these descriptive terms. Adjectives and adverbs are descriptive word classes, and being descriptive, they aim at evaluating their objects described. Obviously, this situation is one that is unpleasant to the larger section of the Ghanaian society and this is made abundantly clear with the use of these evaluative terms. Other evaluative adverbs used in the editorials which have not been recorded as data are justifiably, famously, convincingly, ominously, unfortunately, indefinitely, primarily, promptly and technologically. Some adjectives which were not recorded as data: sad, incompetent, malicious, deviant, inalienable, absurd and ungovernable. These evaluative adjectives and adverbs succinctly portrayed different shades of attitudes as judgments by the writers. These attitudes were geared towards influencing opinions and promoting critical thinking on the part of the people.

Under this aspect of language use, Van Dijk's Media Discourse theory is brought to bear as the evaluative expressions basically aim at communicating a certain ideology to readers. As earlier stated, the state of affairs described by the writer is one of disgust. Therefore the deliberate use of these descriptive disgusting adjectives has the primary purpose of drumming home an ideology of an insensitive class of leaders who take the people for granted with their self-seeking attitude.

\section{Modality Through the Use of Reporting Verbs}

In the data collected, modality was again expressed through the use of certain reporting verbs such as claim, demand, expect, prefer and doubt. The reporting verbs reflected the editorial writers' opinions and attitudes towards the truth value of the content, that is, the extent to which they considered a proposition as true or false.

The Systemic Functional Linguistics principle of modality is expressed here since the choice of these reporting verbs is aimed at drumming home a particular message. Language as a meaning potential is here demonstrated by the use of reporting verbs to evaluate the truth value of propositions made.

Examples found in the editorials were:

1. Government claims that it is exploring the use of an electronic pipeline 
surveillance system to monitor oil theft.

2. We demand to know from the minister how much was spent on potable water provision by this administration in their first year in office.

3. One expects the people to weigh the serious consequences of cholera so that they would do everything possible to avoid it.

4. This association seems to have outstayed its usefulness and no longer champion or foster the interest of the masses.

5. In the period of Lent, every devout Christian was expected to understand more and know more about the faith.

6. Most Ghanaians would definitely prefer to pay for quality education than have a free one compromised in terms of quality.

7. The teaming youth of today doubt almost every policy by government largely due to infidelity on the part of past governments.

8. It appears most people are not enlightened on the TIN registration exercise.

9. It looks like the deputy minister goofed in the deal.

10. We suspect foul play in the death of one of our own here at the GNPC.

11. No one seems to support her recent comments on the CNN.

\section{Generic Phrases of Modality}

These are phrases beginning with expressions such as:

1. It is shameful that ...

2. It is equally cheering that...

3. It is good that...

4. We recognize that...

5. It is disheartening, however that...

The editorial writers revealed their opinions and judgments towards certain propositions through this form of modality as exemplified in the following excerpts.

1. It is disheartening, however, that this forum which is supposed to be an independent body of mature, responsible and knowledgeable elected political leaders, who contribute to national development, as a strong progressive body is now facing allegations of external manipulation by the President.

2. It is doubtful whether every Christian did derive the benefit that should accrue from the year of faith judging from the number that turned out at the various catechesis organized during the period.

3. It is shameful that without an account to the Ghanaian public or even an apology for that waste, the government is thinking of another money guzzling enterprise that may yet again, become a train pipe.

4. It is equally cheering that all regional health facilities in the country have been directed to provide free services to cholera patients. 
5. It is perilous for Ghanaians not to have access to potable water.

6. It is frightening and a shame to this administration that such basic hygiene problems still happen in the country in this age.

The editorial writers employed several linguistic devices to achieve modality to express their attitudes and opinions towards the truth of the propositions expressed in the sentences. To evaluate opinions about the described events, they employed modal auxiliaries, adverbs, adjectives, certain reporting verbs as well as verbs of knowledge and generic phrases.

We see the application of the SFL principle of modality at play here once again. As the theory argues about language as being meaning potential and based on the choices one makes, the editorial writers made these deliberate choices of generic modalities to realise the meanings that one can evidently derive from the statements.

\section{The Use of Rhetorics}

Another linguistic device used in the editorials was rhetorics. The rhetorics promoted critical thinking and produced a sharp effect on readers. The use of this device was more prominent in editorials that are ecclesiastical in nature.

Examples from the excerpts were:

1. Why should the country be subjected to such agonizing experience with its attendant socio-economic consequences?

2. Is it not a shame that in spite of Ghana's wealth and loud claims to civility and development, we cannot keep our youths in school for one uninterrupted academic year or more?

3. Why do wealthy Ghanaians prefer to send their wards abroad for tertiary education even to less endowed sister countries like Togo?

4. Is it not because their educational system is stabilized and they do what they have to do at every point in time?

5. Where are the so-called patriots when our country is sinking deeper and deeper in corruption?

6. Why won't they intervene promptly to nip corruption in the bud?

7. To what extent have the experience helped Christians who are victims of modern trend of atheism, secularism and syncretism to purge themselves of lack of faith?

8. Have the various catechesis and talks that featured during the year of faith translated to greater conviction in our doctrine and belief in the three persons in one God at times no matter what challenges are being faced?

9. To what extent has the year of faith enabled the various target groups to start performing their roles better than before?

10. What about Christians of various vocations and professions? How far did the past 12 months energize them to place Christ first in the discharge of their daily duties as a manifestation of their faith?

11. What difference has our exposure in the year of faith made in our people as a church or community? 
12. Those who used to take bribes, those who resort to divination or occultic means at the slightest challenge, have they stopped such practices? In other words has our faith been deepened?

13. If the regional boards cannot organize a free and fair election for themselves at their level, what do they expect to see at the district levels?

Clearly, rhetorics were used to influence readers and draw their attention to the state of affairs being discussed. The use of the device evoked emotional effects on the readers. The message is better drummed home with the use of this powerful communicative device as it emphasises the unpardonable nature of actions or inactions and the extent of absurdity in the state of affairs being reported.

The reader's sense of critical thinking is thus impressed upon by the writer's use of rhetorics.Van Dijk's media discourse theory applies here strongly as we are given the chance to tap into the understanding levels of the reader and the writer with the use of these rhetorics.

\section{Use of Idioms}

Palmer (2002:2) explains that 'idioms are a colourful and fascinating aspect of English'. Idioms were also used to describe events especially for thought provoking issues. The editorial writers make an attempt to tickle the minds of readers to think critically about the issues they put on the table. One may also argue that the use of idioms is a strategy by writers to attract readers since idioms are part of the spice of language. By this therefore, the writers validate their information to the reader, making the reader more likely to buy into the propositions and ideologies expressed in the editorials.

Some examples from the study include:

1. Despite the undue delay in paying the allowances, I believe it is better late than never.

2. Government over the last two weeks has been working hard behind the scenes to nip the strike in the bud.

3. Beating its chest, Government says that out of the key policy objectives, three critical ones have been tackled so far, citing Free SHS.

4. The country has clearly made $a$ wrong turn.

5. His demeanour that evening speaks volumes of the kind of person we have as our leader.

6. Our country continues to remain a shadow of itself in terms of realising the dreams of its founding father.

7. Most children throw up upon taking the cholera vaccine.

8. We must weather the storm to help the teaming masses of our nation who undeservedly are wallowing in abject poverty.

These idioms used in the editorials also added colour to the ideas presented. Thus, they have sharp, stronger meanings which sustains reader attention, thereby increasing their chances of being influenced by the attitudes and beliefs of the 
reporters and the people they report on. All these add to how language can be used as a tool to influence society and human life in general.

The impact of idioms in the study bears direct link to Van Dijk's media discourse theory in which he stresses the fact that media discourse analysis allows us to tap into the minds of the author and the audience to know their levels of understanding of the issues at table. The writer demonstrates sufficient understanding or knowledge of the state of affairs or information being conveyed by his ability to use idioms to depict reality about his ideology which he seeks to sell to his audience. The reader on the other hand is challenged by the fascinating, spicy language to endear himself to a better understanding of the ideology being communicated to him by the writer.

\section{Conclusion}

From the foregoing analysis, it is clear that the language of editorials is thought provoking, evaluative, persuasive and sophisticated. The editorial writers used different linguistic devices to achieve these. They used different linguistic devices in the form of modality, evaluative adjectives and adverbs, generic phrases, rhetorics, and idioms to express different shades of attitude and opinion, to influence, shape or re-shape their readers' attitudes and to promote critical thinking on the part of their readers. The writers used these devices to state different kinds of claims, and opinions, thereby assessing the potentiality of the state of affairs in the society and making judgments thereupon. To this end, language is seen as being influential: it indicts, persuades and empowers people. Language influences ideologies. This confirms the hypothesis of the study that language can be used in particular ways, so intended by the user, to achieve specific purposes. The editorial authors in this study have abundantly demonstrated this organic characteristic of the very nature and function of language.

\section{References}

Abraham, M. and Harpham, G. 2005. A glossary of literary terms. Cornell: Holt Reinhart and Winston.

Ajayi, H. 2017. English as a second language learners' exploration of multimodal texts in a Junior High School. Lagos: Lutron Publishers.

Aldler, R.B. and Rodman, G. 2016. Understanding human Communication. USA: Harcourt College Publishers.

Anigbogu N.C. 2015. Linguistic Devices in Media Discourse: A Case Study. International Journal of English Language and Linguistics.

Bilal, H.A., Rafaquet, U., Hassan, N., Mansoor, H. and Zahra, Q. 2012. Editorials of Pakistani English print media: Application of CDA. International Journal of Linguistics, 4 (3) 746.

Boyd-Barret, O. 2014. Language and media: A question of convergence. In: D. Graddol \& O. Boyd-Barret (eds). Media texts: authors and readers. (pp. 22-39).

Brown, G. and Yule, G. 1983. Discourse analysis. Cambridge: Cambridge University 
Press.

Cameron, D. 2007. The teacher's guide to grammar. Oxford: Oxford University Press. Finegan E. 2012. Language: Its structure and use. USA: Wadsworth Language learning. Malcolm, X. 1997. Discovering language. In: P. Eschololz, A. Rosa \& V. Clark (eds.) Language Awareness. New York: St. Martin's Press, (pp. 11-15).

Malmkjaer, K. and Anderson, J.M. (Eds.) 1991. The linguistics encyclopaedia. London: Routledge.

Norquist, R. 2013. Discourse analysis. Retrieved from grammar.about.com/ord/d/g/disana lysisterm.htm.

Opara, S.C. 2009. Aspects of functional grammar: A systemic approach. Enugu: Victojo Production Services.

Opara S.C. 2011. Topics in discourse analysis. Owerri: Gabtory and Associates Ltd.

Palmer, F.R. 2002. Semantics. United Kingdom Cambridge University Press.

Sheperd, L. 2013. Writing tips for editorial. Retrieved from http://www.howtodothings. com/hobbies/94439-how-to-writ-an-editorial.html

Weintraut, A. 2013.Writing an editorial. Retrievedfromhttp://ww.geneseo.edu/bennet/Edw rite.htm

Wikipedia (2018). Discourse analysis. Retrieved from http://en.wikipedia.org/w/discour seanalysis

Google Scholar. (2018). Ghanaian Newspaper Editorials. Retrieved from http:/en.wikipe dia.org/wiki/editorial

Van-Dijk, T. (1998). Opinions and Ideologies in the press. Retrieved from http://www. howtodothings.com/hobbies/94439-how-to-writ-an-editorial.html1998 


\section{Appendix}

\section{Data Sources}

In table one, the source of each excerpt from the editorials used in this study is indicated. The serial number of each editorial excerpt is indicated in the first column of the diagram to the left in vertical order. The six different linguistic choices examined in the study are typed out in bold in the top first column of the table in horizontal order. Each box contains vivid description of the source of an excerpt: name of newspaper (e.g DGr), page (p.12) and then the date of publication (27/8/17).This is to make it possible for readers to verify the sources of the data.

Key:

GT=The Ghanaian Times,

DGr=The Daily Graphic,

$\mathbf{C G}=$ The Crusading Guide,

CS=The Catholic Standard,

TI=The Insight,

DGu= The Daily Guide,

TM=The Mirror,

TInd.=The Independent.

Table 1. Editorial References from Selected Newspapers

\begin{tabular}{|c|c|c|c|c|c|c|}
\hline $\begin{array}{l}\text { SN. of } \\
\text { Excerpt }\end{array}$ & Modality(21) & $\begin{array}{c}\text { Evaluative } \\
\text { Adj. \& } \\
\text { Adv.(12) }\end{array}$ & $\begin{array}{c}\text { Modality } \\
\text { via Rep. } \\
\text { Verb(11) } \\
\end{array}$ & $\begin{array}{c}\text { Generic } \\
\text { Modality(6) }\end{array}$ & $\begin{array}{c}\text { Use of } \\
\text { Rhetorics } \\
(13) \\
\end{array}$ & $\begin{array}{c}\text { Use of } \\
\text { Idioms(8) }\end{array}$ \\
\hline 1 & $\begin{array}{l}\text { GT,p14 } \\
27 / 1 / 18\end{array}$ & $\begin{array}{l}\text { TM,p21 } \\
17 / 3 / 18\end{array}$ & $\begin{array}{l}\text { CG,p7 } \\
5 / 9 / 17\end{array}$ & $\begin{array}{c}\text { DGu,p18 } \\
18 / 3 / 18\end{array}$ & $\begin{array}{c}\text { TI,p3 } \\
16 / 3 / 18\end{array}$ & $\begin{array}{l}\text { TInd.,p7 } \\
15 / 4 / 18\end{array}$ \\
\hline 2 & $\begin{array}{c}\text { DGr,p6 } \\
9 / 11 / 2017\end{array}$ & $\begin{array}{c}\text { GT,p3 } \\
13 / 11 / 17\end{array}$ & $\begin{array}{c}\text { TInd.,p13 } \\
18 / 11 / 18\end{array}$ & $\begin{array}{l}28 / 1 / 18 \\
\text { CS,p15 }\end{array}$ & $\begin{array}{l}\text { TM,p18 } \\
\text { 19/1/18 }\end{array}$ & $\begin{array}{l}\text { CG,p19 } \\
17 / 2 / 18\end{array}$ \\
\hline 3 & $\begin{array}{c}\text { CG,p11 } \\
28 / 12 / 2017\end{array}$ & $\begin{array}{c}\text { DGu,p9 } \\
8 / 2 / 18\end{array}$ & $\begin{array}{l}\text { CG,p22 } \\
3 / 12 / 17\end{array}$ & $\begin{array}{l}\text { TM,p6 } \\
\text { 4/8/17 }\end{array}$ & $\begin{array}{l}\text { GT,p18 } \\
30 / 1 / 18\end{array}$ & $\begin{array}{l}\text { TInd.,p11 } \\
23 / 11 / 17\end{array}$ \\
\hline 4 & $\begin{array}{l}\text { TI,p17 } \\
4 / 3 / 18\end{array}$ & $\begin{array}{l}\text { CG,p17 } \\
19 / 1 / 18\end{array}$ & $\begin{array}{c}\text { DGu,p19 } \\
14 / 1 / 18\end{array}$ & $\begin{array}{c}\text { GT,p9 } \\
27 / 11 / 17\end{array}$ & $\begin{array}{c}\text { TI,p23 } \\
14 / 3 / 18\end{array}$ & $\begin{array}{c}\text { CG,p9 } \\
29 / 10 / 17\end{array}$ \\
\hline 5 & $\begin{array}{c}\text { DGu,p14 } \\
18 / 3 / 18\end{array}$ & $\begin{array}{l}\text { TInd.,p2 } \\
\text { 27/9/17 }\end{array}$ & $\begin{array}{c}\text { 19/10/17 } \\
\text { CS,p14 }\end{array}$ & $\begin{array}{c}\text { CG,p13 } \\
15 / 12 / 17\end{array}$ & $\begin{array}{c}\text { CG,p21 } \\
23 / 10 / 17\end{array}$ & $\begin{array}{l}\text { TM,p19 } \\
30 / 9 / 17\end{array}$ \\
\hline 6 & $\begin{array}{c}\text { TM,p17 } \\
27 / 10 / 17\end{array}$ & $\begin{array}{c}\text { TI,p14 } \\
\text { 20/8/18 }\end{array}$ & $\begin{array}{l}\text { TM,p8 } \\
6 / 3 / 18\end{array}$ & $\begin{array}{c}\text { TI,p19 } \\
12 / 2 / 18\end{array}$ & $\begin{array}{c}\text { DGr,p2 } \\
17 / 10 / 17\end{array}$ & $\begin{array}{l}\text { DGr,p14 } \\
21 / 11 / 17\end{array}$ \\
\hline 7 & $\begin{array}{c}\text { TInd.,p4 } \\
5 / 9 / 17\end{array}$ & $\begin{array}{c}\text { CG,p11 } \\
7 / 3 / 18\end{array}$ & $\begin{array}{l}\text { DGr,p15 } \\
29 / 11 / 17\end{array}$ & & $\begin{array}{c}27 / 11 / 17 \\
\text { CS,p14 }\end{array}$ & $\begin{array}{c}\text { DGu,p4 } \\
4 / 2 / 18\end{array}$ \\
\hline 8 & $\begin{array}{l}\text { TInd.p88 } \\
\text { 28/9/17 }\end{array}$ & $\begin{array}{c}\text { TInd.,p12 } \\
15 / 9 / 18\end{array}$ & $\begin{array}{c}\text { TI,p17 } \\
21 / 2 / 18\end{array}$ & & $\begin{array}{c}4 / 4 / 18 \\
\text { CS,p18 }\end{array}$ & $\begin{array}{c}\text { TI,p6 } \\
19 / 4 / 18\end{array}$ \\
\hline 9 & $\begin{array}{c}\text { TM,p9 } \\
16 / 1 / 18\end{array}$ & $\begin{array}{l}\text { DGr,p17 } \\
28 / 11 / 17\end{array}$ & $\begin{array}{c}\text { TI,p3 } \\
16 / 4 / 18\end{array}$ & & $\begin{array}{c}29 / 10 / 17 \\
\text { CS,p24 }\end{array}$ & \\
\hline 10 & $\begin{array}{l}\text { DGu,p10 } \\
29 / 12 / 17\end{array}$ & $\begin{array}{c}\text { DGr,p9 } \\
9 / 8 / 17\end{array}$ & $\begin{array}{c}\text { DGu,p12 } \\
25 / 3 / 18\end{array}$ & & $\begin{array}{c}\text { 20/9/17 } \\
\text { CS,p1 }\end{array}$ & \\
\hline 11 & $\begin{array}{c}\text { TI,p18 } \\
23 / 2 / 18\end{array}$ & $\begin{array}{c}\text { GT,p4 } \\
17 / 10 / 18\end{array}$ & $\begin{array}{l}\text { DGr,p20 } \\
24 / 10 / 17\end{array}$ & & $\begin{array}{l}17 / 1 / 18 \\
\text { CS,p10 }\end{array}$ & \\
\hline
\end{tabular}




\begin{tabular}{|c|c|c|c|}
\hline 12 & $\begin{array}{c}\text { CG,p7 } \\
30 / 8 / 17\end{array}$ & $\begin{array}{c}\text { TM,p8 } \\
29 / 10 / 17 \\
\end{array}$ & $\begin{array}{c}\text { DGu,p14 } \\
9 / 3 / 18 \\
\end{array}$ \\
\hline 13 & $\begin{array}{c}\text { DGr,p13 } \\
13 / 4 / 18\end{array}$ & & $\begin{array}{c}\text { TInd.,p13 } \\
12 / 8 / 17\end{array}$ \\
\hline 14 & $\begin{array}{l}\text { GT,p16 } \\
26 / 2 / 18\end{array}$ & & \\
\hline 15 & $\begin{array}{c}\text { TM,p6 } \\
3 / 10 / 17 \\
\end{array}$ & & \\
\hline 16 & $\begin{array}{l}\text { DGu,p15 } \\
20 / 11 / 17\end{array}$ & & \\
\hline 17 & $\begin{array}{l}\text { GT,p17 } \\
19 / 2 / 18\end{array}$ & & \\
\hline 18 & $\begin{array}{c}\text { TI,p1 } \\
15 / 4 / 18\end{array}$ & & \\
\hline 19 & $\begin{array}{l}\text { CG,p17 } \\
31 / 1 / 18\end{array}$ & & \\
\hline 20 & $\begin{array}{l}\text { DGr,p6 } \\
\text { 21/3/18 }\end{array}$ & & \\
\hline 21 & $\begin{array}{c}\text { TInd.p,9 } \\
\text { 2/4/18 }\end{array}$ & & \\
\hline
\end{tabular}


